\title{
1 Pharmaceuticals and personal-care products in plants
}

2 Mireia Bartrons, ${ }^{1,2 *}$ Josep Peñuelas ${ }^{2,3}$

3

$4 \quad{ }^{1}$ BETA Technological Centre (Tecnio), Aquatic Ecology Group, University of Vic-Central

5 University of Catalonia. Vic 08500, Barcelona, Catalonia, Spain.

$6{ }^{2}$ CSIC, Global Ecology Unit CREAF-CSIC-UAB. Bellaterra 08193, Barcelona, Catalonia,

7 Spain.

$8 \quad{ }^{3}$ CREAF. Cerdanyola del Vallès 08193, Barcelona, Catalonia, Spain.

9

10

*Corresponding author: mireia.bartrons@uvic.cat (M. Bartrons)

This is the author's version of a work that was accepted for publication in Trends in plant science (Ed. Elsevier). Changes resulting from the publishing process, such as peer review, editing, corrections, structural formatting, and other quality control mechanisms may not be reflected in this document. Changes may have been made to this work since it was submitted for publication. A definitive version was subsequently published in Bartrons, M. and Peñuelas, J. "Pharmaceuticals and personal-care products in plants" in Trends in plant science, vol. 22, issue 3 (March 2017), p. 194-203. DOI 10.1016/j.tplants.2016.12.010 
Pharmaceuticals and personal-care products (PPCPs) derived from agricultural and urban areas accumulate in plants at concentrations (ng to $\mu \mathrm{g} \mathrm{kg}^{-1}$ ) that can be toxic for plants. Importantly, the dietary intake of these PPCP-contaminated plants may also pose a risk to human health, but currently little is known about the fate of PPCPs in plants and their effect or risk to the ecosystem. In this opinion article we propose that in-depth research on the use of plants as a monitoring device for assessing the use and environmental presence of PPCPs is warranted. The toxicity of PPCPs to plants and their microbiota needs to be established, as well as any toxifying effect to plant herbivores, humans included..

\section{Pharmaceuticals and personal-care products in plants and food webs}

Plants act as excellent tracers of global pollution [1], because they are present in almost all areas of the planet and accumulate chemical compounds present in the atmosphere, the water with which they are irrigated, and the soil on which they grow. Thousands of new chemical compounds have been continuously produced every year since the industrial revolution to facilitate our lives. Some of these substances, such as heavy metals and persistent organic pollutants (POPs), are toxic and widely distributed, and their synthesis and use have been substantially regulated [2]. Several have been documented by using plants as natural biomonitors of environmental pollution [2]. Technical development in the field of environmental chemistry has recently led to a new and increasing concern over the environmental risks of a new group of chemicals - 'contaminants of emerging concern' [3].

'Contaminants of emerging concern' mostly include pharmaceuticals and personal-care products (PPCPs), such as analgesics and anti-inflammatories, anti-diabetics, anti-epileptics, anti-estrogenics, anti-protozoals, antiseptics, lipid regulators, diuretics, medications for treating erectile dysfunction and pulmonary arterial hypertension, psychiatric drugs and antidepressants, 


\section{Environmental sources and pathways of transport to plants}

psycho-stimulants, veterinary and human antibiotics, $\beta$-blockers, $X$-ray and contrast media, cosmetics and personal-care products, surfactants and phytosanitary products (Table 1). Assessing the risks of all these compounds within a reasonable time frame is very difficult, due to the large number of new substances developed every year [4]. More than 4000 pharmaceuticals are currently in use; the total global consumption of antibiotics is estimated at 100000-200000 tons, approximately 15000 tons $\mathrm{y}^{-1}$ of antibiotics are released into the European environment alone [5]. The great advances in the detection and analysis of trace regulation have not currently been recognized and established. In fact, PPCP emission to the 1). These PPCPs are taken up, accumulated and metabolized by plants, which may affect the plants, their microbiota and the organisms feeding on them, including humans. We here present the current limited knowledge on the life cycle of PPCPs and their effect on the environment and call for further research on the use of plants as a monitoring device for assessing the fate to herbivores, humans included, as well as any toxic effect to plants and their microbiota.

PPCPs in the environment are mainly associated with municipal, agricultural and industrial wastewater sources and pathways [7-9]. Point-source contamination with 'contaminants of emerging concern' includes discharges or leaks of domestic, hospital or industrial wastewater (conventional secondary processes such as the use of activated sludge and trickling filters are not designed to remove PPCPs from influent water); application of sewage sludge to land; pollutants during recent decades indicate that PPCPs are very frequently detected anthropogenic contaminants in the environment [6]. Not all PPCPs are newly designed compounds. Some have been dispersed into the environment over a long period of time, but their presence, toxicity and environment is mostly associated with human activities and the discharge of wastewater (Figure and environmental presence of PPCPs. Research is needed into the toxicity of these compounds pharmaceuticals and pesticides voided by treated animals in manure or applied to agricultural 
land or water (aquaculture facilities); leaching from disposed solid waste; pesticide applications and disposal of carcasses of treated animals. Diffuse pollution includes agricultural runoff from biosolids (treated sewage sludge intended for agricultural use as a soil conditioner) and manure, storm-water and urban runoff, leakage from reticulated urban sewage systems and diffuse aerial deposition.

The pathways of transport for PPCPs through air, water or soil are difficult to characterize due to the little information on the fate and behavior in the environment for most of these compounds but will depend on their physicochemical properties, such as solubility in water, coefficient of octanol-water partition Kow (surrogate of a chemical partition between an organic and aqueous phase) or persistence and on the properties of the surrounding matrices (such as water or soil) [10]. Dust [11] or microplastics [12] may also play an important role in the entry of non-volatile PPCPs to the environment.

PPCPs reach plants mainly from the use of reclaimed wastewater for irrigation, the application of biosolids (treated sewage sludge) and manure for the fertilization of agricultural soils and from deposition from volatilized compounds. PPCPs tend to dissolve relatively easily in water and do not evaporate at normal temperatures, so they often end up in soil and water bodies.

The use of treated wastewater for agricultural irrigation is becoming common, especially in arid and semi-arid regions. For example, more than 85,71 and $46 \%$ of treated wastewater is used for agricultural irrigation in Israel, Spain and California, respectively [13]. With the current climatic projections, these percentages may dramatically increase in these and other countries. The concentrations of PPCPs in irrigated agro-ecosystems will accordingly increase due to the occurrence and accumulation of PPCPs in reused water, also increasing the potential for plant uptake and subsequent human exposure by ingestion [14].

Biosolids are rich in minerals and organic compounds and are therefore added to soils to improve soil fertility, restore organic matter, improve the physicochemical and biological features of soils, facilitate the resettlement of plants and restore altered communities [15]. This 
practice will become crucial for the sustainability of agriculture due to the growing population and lack of nutrients (mostly phosphorus) [16]. In the U.S., for example, 55\% of biosolids are applied to soils and $45 \%$ are landfilled or incinerated [17]. The safety of this practice is, however, constantly discussed due to the amounts of antibiotics, non-steroidal antiinflammatories, anti-convulsants and other PPCPs that biosolids may transfer to soils.

Veterinary antibiotics are the most abundant PPCPs in manure. The detected concentrations of these compounds are very variable among source species and type of operation but range from 0.1-46.0, 0.1-24.4 and $<0.5 \mathrm{mg} \mathrm{kg}^{-1}$ in Germany, Denmark and Turkey, respectively [18]. Antibiotics are persistent, with long half-lives in soils.

Knowing the amounts of PPCPs in wastewater, biosolids and manure before they are applied to agro-system soils is thus crucial to avoid possible problems of toxicity for plants, their microbiota and animals, including humans, feeding on them. PPCPs from wastewater, biosolids and manure, though, are not regularly monitored and therefore are not considered in the decision to irrigate soils with wastewater, amend them with biosolids or fertilize them with manure.

\section{Plant uptake, bioaccumulation and metabolization}

The uptake of PPCPs by plants is receiving increased attention. Large amounts of PPCPs have been found in various species and tissues [3,19-23], with highly variable concentrations, ranging from no detection to $487 \mu \mathrm{g} \mathrm{kg}^{-1}$ (Table 2). Antibiotics are usually the most abundant PPCPs in plants due to their high concentrations in the biosolids and animal manure applied to agricultural fields [19]. The physicochemical properties of the compounds (such as hydrophobicity and ionization behavior) greatly influence the uptake, accumulation, translocation and transformation of PPCPs in plants. The physiological nature of the plant and its tissues, soil properties (such as $\mathrm{pH}$ and organic matter content), water quality and exposure concentration and duration also affect the uptake and accumulation of PPCPs. 
115 The pathways of the uptake and bioaccumulation of PPCPs in plants, however, are not well

116 understood [22]. Plants take up PPCPs through roots and aerial tissues (Figure 2). Roots take up

117 PPCPs by mass flow or the diffusion of dissolved compounds into roots [24]: neutral

118 compounds diffuse across the root-cell membrane with a partition very similar to the partition to

119 octanol, and ionizable compounds enter roots by a combination of diffusion of the neutral

120 fraction and electrostatic interactions of the ionic fraction. Aerial tissues take up PPCPs via

121 deposition from volatilized compounds and aerosols, direct contact (diffusion or ionic fraction

122 uptake) with irrigation or amendment materials and translocation from root tissues [25].

123 Hydrophobic compounds may partition to lipids and will be predominantly retained by roots,

124 while most hydrophilic compounds will move to the xylem (in equilibrium with the water),

125 from which nonionic PPCPs accumulate in leaves, transported predominantly in the direction of

126 the transpiration stream, and ionic PPCPs, repelled by the negatively charged cell walls and

127 cytosol, may be trapped in the phloem and can accumulate more in the fruit [26]. Metabolic

128 enzymes, such as hydrolases or cytochrome p450, transform the PPCPs once they are in the

129 plant cells, creating a variety of transformation products, which are eventually mineralized or

130 incorporated into the plant tissue [27]. PPCP metabolites are also produced in plants for treating

131 wastewater or in soils, and their concentrations and biological activities are similar or even

132 higher than those of the PPCP parental compounds [28], but less is known about their uptake by

133 plants.

\section{Toxicity}

136 Exposure to PPCPs may affect plant development, either as a result of direct damage to the plant (decreased photosynthetic pigments, reduced number and size of mature leaves, inhibition of root elongation or negative effects on growth and development) (Table 2) or as a result of the antimicrobial action of pharmaceuticals on plant microbiota $[29,30]$ and on soil microorganisms that affect plant-microorganism symbiosis and nutrient cycling in soils [31]. The specific 
141 effects on each plant species obviously depend on the compound, compound concentration, and

142 plant species. A recent review shows that most studies only tested the effects of individual

143 compounds and frequently at concentrations much higher than are environmentally relevant

144 [31]. Some recent studies, however, report adverse effects of PPCPs on natural populations of

145 plants at environmental concentrations, for example decreased plant growth and crop production

146 (Table 2). Other studies have found no phytotoxic effects at environmental PPCP levels [32,33].

147 The toxic effects of most compounds of emerging concern on plants, their microbiota and entire

148 ecosystems are thus still far from clear, but the few data available and the likely effects of many

149 PPCPs such as antibiotics warrant further research.

150 Most assessments of the risks of PPCPs on both environmental end-points and human receptors

151 indicate that the risk of adverse effects in the various trophic levels of food webs or in human

152 health could be low [e.g. ,34]. The assessments are based on the low concentrations of PPCPs in

153 plants and the low toxicity of most compounds (exposure levels are usually below human

154 therapeutic dose levels or acceptable daily intakes). The potential toxic effects of PPCPs on

155 organisms, however, are an increasing concern, with particular emphasis on the microbiomes

156 (bacteria, fungi and archaea that live on and in organisms' bodies) of humans and other animals,

157 due to (a) the long-term exposure to these compounds (even at low levels), (b) the little

158 comprehensive information on the fate and effects in the environment and the lack of

159 pharmacovigilance programs examining the environmental effects [35], (c) the effects of the

160 transformation products with potentially greater health concerns than their parental compounds,

161 (d) the possible synergistic effects between PPCPs and other micropollutants or medicines taken

162 by a patient for an existing condition, (e) the multiple routes of exposure of PPCPs (most studies

163 of risk assessment have only considered one route of exposure) and (f) the increasing selection

164 of antibiotic-resistant microorganisms in the environment, including pathogens.

165 In fact, some PPCPs may have dramatic adverse effects on wildlife such as tadpoles, aquatic

166 invertebrates, fish, earthworms and birds and on soil microbial communities, even at very low

167 levels of exposure [7,36,37]. Some of the first and most famous cases of PPCP toxicity for 
example were observed after the extremely rapid massive decline (>95\%) of the population of oriental white-backed vultures caused by the residues of veterinary diclofenac in scavenged cattle carcasses [38], or after the collapse of the population of fathead minnows caused by the exposure to low concentrations $\left(5-6 \mathrm{ng} \mathrm{L}^{-1}\right)$ of the synthetic estrogen vitellogenin [39]. Further attention has recently been given to the effects of human and veterinary antibiotics. They dramatically affect the structure and function of soil microbial communities and promote the emergence of multi-drug resistant human pathogens that increasingly threaten the successful antibiotic treatment of bacterial infections [40]. The variability of the effects of PPCPs and their metabolites on humans and the entire biosphere, even at low concentrations, indicates that more research is needed to clarify the ecotoxicology of PPCPs. Most of these compounds are quite persistent, and tonnes are emitted every year into the environment, contaminating groundwater, supplies of drinking water, streams and agricultural land to an unprecedented degree.

\section{Regulation, plant monitoring and decontamination methods}

Due to the lack of data on the fate of PPCSs in the environment and the toxicity to plants and humans, no regulations exist for most PPCPs in irrigation water, biosolids or manure before being reused for agriculture or in supplies of drinking water, vegetables and other food to be commercialized. Some of these compounds will likely soon be included in the list of priority organic pollutants of updated versions of the Water Framework Directive. Less is done for unknown chemicals, which should also be evaluated using effect-based trigger values that account for multiple chemical mixtures [41], and then accordingly regulated.

In addition to the required regulations and the innovation of treatment techniques, large-scale monitoring of the fate of PPCPs in the global environment should be prioritized, with special attention to vegetables cultivated with biosolids, manure or re-used irrigation water, in addition to drinking water. The analysis of PPCPs in plants as natural passive samplers of PPCPs in the global environment would be an excellent and relatively cheap tool to assess both the historical 
and spatial fate of PPCPs in various ecosystems and to identify their sources. The use of plants as biomonitors of pollution (e.g. persistent organic pollutants and heavy metals), due to the widespread distribution of plants and to their ability to absorb a diverse range of chemicals from the air, water and soil, has indeed gained increased attention in recent years [1,2]. In fact, some studies are starting to develop pilot pan-European monitoring of current priority and emergent compounds, but using sentinel raptors, not plants [42]. We reinforce the need to track the environmental fate of PPCPs by also using plants. Plants are sessile and often in direct contact with wastewater from irrigation or the application of biosolids and manure to soils, so they are key for tracing point-source contamination. Plants occupy the first trophic positions in food webs and so are the principal route for the exposure of ruminants and humans to PPCPs.

Improving the methods of wastewater decontamination to remove and remediate PPCPs from plants for treating wastewater is also crucial [43]. Some of these methods of purification include sludge activation, nitrification, sand-filtering, aeration of sludge with ferrous chloride, oxygen activation, biological contractors and chlorination. Even the most efficient of these methods (two-step sludge activation), however, require up to 49 days of processing and cannot completely remove PPCPs. This processing is too slow, considering the extremely high daily emission of PPCPs to the environment, including agro-systems, groundwater and drinking water.

\section{Concluding remarks}

PPCPs facilitate everyday life in our society. Thousands of new substances are developed every year, and thousands of tons are consumed and emitted to the sewage system, mostly in large urban centers. PPCP removal from plants for wastewater treatment is incomplete, and the dispersal of these compounds into the environment and accumulation in plants mostly occurs from irrigating with reused water and the application of biosolids and manure to land. Plants thus become a monitoring device for assessing the use and environmental presence of PPCPs. 

soil microorganisms that affect plant-microorganism symbiosis and nutrient cycling. An indepth understanding of the behavior and fate of PPCPs in plants is unfortunately lacking. The health risk to ecosystems and humans that the dietary intake of these PPCP-contaminated plants (mostly crops) pose is even more uncertain (see also outstanding questions). For example, the influences of PPCPs on the human microbiome are increasing the threat of multi-drug resistant human pathogens. Improved toxicological studies of the short- and long-term impacts of relatively low doses of the many PPCPs in the environment, the regulation of PPCPs, the development of extensive spatiotemporal protocols for monitoring water, soils, plants and humans and the innovation of treatment techniques are key for the future safety of drinking water and the fertilization of agro-systems with reused irrigation water, manure and biosolids.

\section{Bibliography}

$1 \quad$ Lin, V.S. et al. (2015) Research highlights: natural passive samplers - plants as

biomonitors. Environ. Sci. Process. Impacts 17, 1137-1140

2 Bartrons, M. et al. (2016) Spatial And Temporal Trends Of Organic Pollutants In

Vegetation From Remote And Rural Areas. Sci. Rep. 6, 25446

3 Hyland, K.C. et al. (2015) Accumulation of contaminants of emerging concern in food crops-part 1: Edible strawberries and lettuce grown in reclaimed water. Environ. Toxicol. Chem. 34, 2213-2221

4 Boxall, A. (2012) New and Emerging Water Pollutants arising from agriculture. OECD Rep.

5 Manzetti, S. and Ghisi, R. (2014) The environmental release and fate of antibiotics. Mar. Pollut. Bull. 79, 7-15

6 Sui, Q. et al. (2015) Occurrence, sources and fate of pharmaceuticals and personal care products in the groundwater: A review. Emerg. Contam. 1, 14-24

7 Petrie, B. et al. (2014) A review on emerging contaminants in wastewaters and the environment: Current knowledge, understudied areas and recommendations for future monitoring. Water Res. 72, 3-27

8 Naidu, R. et al. (2016) Emerging contaminants in the environment: Risk-based analysis for better management. Chemosphere 154, 350-357

9 Stuart, M. et al. (2012) Review of risk from potential emerging contaminants in UK groundwater. Sci. Total Environ. 416, 1-21

10 Fairbairn, D.J. et al. (2016) Sources and transport of contaminants of emerging concern: A two-year study of occurrence and spatiotemporal variation in a mixed land use watershed. Sci. Total Environ. 551, 605-613

11 Hamscher, G. and Hartung, J. (2008) Pharmaceuticals in the Environment: Sources, Fate, Effects and Risks. (Kümmerer, K., ed), pp. 95-102, Springer Berlin Heidelberg

12 Wu, C. et al. (2016) Sorption of pharmaceuticals and personal care products to polyethylene debris. Environ. Sci. Pollut. Res. 23, 8819-26 
Sato, T. et al. (2013) Global, regional, and country level need for data on wastewater

14 Mohapatra, D.P. et al. (2016) Application of Wastewater and Biosolids in Soil : Occurrence and Fate of Emerging Contaminants. Water Air Soil Pollut. DOI: $10.1007 / \mathrm{s} 11270-016-2768-4$

15 Cogger, C.G. et al. (2013) Long-Term Crop and Soil Response to Biosolids Applications in Dryland Wheat. J. Environ. Qual. 42, 1872

16 Obersteiner, M. et al. (2013) The phosphorus trilemma. Nat. Geosci. 6, 897-898

17 UN-Habitat (2009) Global Atlas of Excreta, Wastewater Sludge, and Biosolids Management: Moving Forward the Sustainable and Welcome Uses of a Global Resource, Programme, United Nations Human Settlements.

18 Kumar, R.R. et al. (2012) Fate, occurrence, and toxicity of veterinary antibiotics in environment. J. Korean Soc. Appl. Biol. Chem. 55, 701-709

19 Matamoros, V. et al. (2012) Analytical procedures for the determination of emerging organic contaminants in plant material: A review. Anal. Chim. Acta 722, 8-20

20 Calderón-Preciado, D. et al. (2013) Uptake of microcontaminants by crops irrigated with reclaimed water and groundwater under real field greenhouse conditions. Environ. Sci. Pollut. Res. 20, 3629-3638

$21 \mathrm{Wu}$, X. et al. (2015) Plant uptake of pharmaceutical and personal care products from recycled water and biosolids: A review. Sci. Total Environ. 536, 655-666

22 Miller, E.L. et al. (2015) Root Uptake of Pharmaceutical and Personal Care Product Ingredients. Environ. Sci. Technol. 50, 525-541

23 Sabourin, L. et al. (2012) Uptake of pharmaceuticals, hormones and parabens into vegetables grown in soil fertilized with municipal biosolids. Sci. Total Environ. 431, 233-6

24 Miller, E.L. et al. (2016) Root Uptake of Pharmaceuticals and Personal Care Product Ingredients. Environ. Sci. Technol. 50, 525-41

25 Trapp, S. and Legind, C. (2011) Uptake of Organic Contaminants from Soil into Vegetables and Fruits. In Dealing with Contaminated Sites (Swartjes, F. A., ed), pp. 369-408, Springer Netherlands

26 Goldstein, M. et al. (2014) Insights into the uptake processes of wastewater-borne pharmaceuticals by vegetables. Environ. Sci. Technol. 48, 5593-5600

27 Bartha, B. et al. (2014) Uptake and metabolism of diclofenac in Typha latifolia--how plants cope with human pharmaceutical pollution. Plant Sci. 227, 12-20

28 Bahlmann, A. et al. (2014) Carbamazepine and its metabolites in wastewater: Analytical pitfalls and occurrence in Germany and Portugal. Water Res. 57, 104-114

29 Peñuelas, J. and Terradas, J. (2014) The foliar microbiome. Trends Plant Sci. 19, 278-80

30 Peñuelas, J. et al. (2014) Removal of floral microbiota reduces floral terpene emissions. Sci. Rep. 4, 6727

31 Carvalho, P.N. et al. (2014) A review of plant-pharmaceutical interactions: from uptake and effects in crop plants to phytoremediation in constructed wetlands. Environ. Sci. Pollut. Res. 21, 11729-11763

32 Jones-Lepp, T.L. et al. (2010) Method development and application to determine potential plant uptake of antibiotics and other drugs in irrigated crop production systems. J. Agric. Food Chem. 58, 11568-73

33 Winker, M. et al. (2010) Ryegrass uptake of carbamazepine and ibuprofen applied by urine fertilization. Sci. Total Environ. 408, 1902-8

34 García-Santiago, X. et al. (2016) Risk assessment of persistent pharmaceuticals in biosolids: Dealing with uncertainty. J. Hazard. Mater. 302, 72-81

35 Boxall, A.B.A. et al. (2012) Pharmaceuticals and personal care products in the environment: what are the big questions? Environ. Health Perspect. 120, 1221-9

36 Boxall, A.B.A. (2004) The environmental side effects of medication. EMBO Rep. 5, $1110-6$

37 Jechalke, S. et al. (2014) Fate and effects of veterinary antibiotics in soil. Trends Microbiol. 22, 536-545 
Oaks, J.L. et al. (2004) Diclofenac residues as the cause of vulture population decline in

39 Kidd, K.A. et al. (2007) Collapse of a fish population after exposure to a synthetic estrogen. Proc. Natl. Acad. Sci. 104, 8897-8901

40 Jechalke, S. et al. (2014) Fate and effects of veterinary antibiotics in soil. Trends Microbiol. 22, 536-545

41 Escher, B.I. et al. (2013) Most oxidative stress response in water samples comes from unknown chemicals: the need for effect-based water quality trigger values. Environ. Sci. Technol. 47, 7002-11

42 Espín, S. et al. (2016) Tracking pan-continental trends in environmental contamination using sentinel raptors-what types of samples should we use? Ecotoxicology 25, 777-801

43 Manzetti, S. and Ghisi, R. (2014) The environmental release and fate of antibiotics. Mar. Pollut. Bull. 79, 7-15

44 Ferrari, B. et al. (2003) Ecotoxicological impact of pharmaceuticals found in treated wastewaters: study of carbamazepine, clofibric acid, and diclofenac. Ecotoxicol. Environ. Saf. 55, 359-370

45 González-Naranjo, V. et al. (2015) Environmental risk of combined emerging pollutants in terrestrial environments: Chlorophyll a fluorescence analysis. Environ. Sci. Pollut. Res. 22, 6920-6931

46 Eggen, T. et al. (2011) Uptake and translocation of metformin, ciprofloxacin and narasin in forage- and crop plants. Chemosphere 85, 26-33

47 Pan, M. et al. (2014) Distribution of antibiotics in wastewater-irrigated soils and their accumulation in vegetable crops in the Pearl River Delta, Southern China. J. Agric. Food Chem. 62, 11062-11069

48 Hillis, D.G. et al. (2011) Effects of Ten Antibiotics on Seed Germination and Root Elongation in Three Plant Species. Arch. Environ. Contam. Toxicol. 60, 220-232

49 Kumar, K. et al. (2005) Antibiotic Uptake by Plants from Soil Fertilized with Animal Manure. J. Environ. Qual. 34, 2082

50 Grote, M. et al. (2007) Incorporation of veterinary antibiotics into crops from manured soil. Landbauforsch. Völkenrode 157, 25-32

51 Michelini, L. et al. (2012) Sulfadiazine Uptake and Effects on Salix fragilis L. and Zea mays L. Plants. Water, Air, Soil Pollut. 223, 5243-5257

$52 \mathrm{Hu}, \mathrm{X}$. et al. (2010) Occurrence and source analysis of typical veterinary antibiotics in manure, soil, vegetables and groundwater from organic vegetable bases, northern China. Environ. Pollut. 158, 2992-2998

53 Liu, F. et al. (2009) Effects of six selected antibiotics on plant growth and soil microbial and enzymatic activities. Environ. Pollut. 157, 1636-1642

$54 \mathrm{Wu}, \mathrm{C}$. et al. (2010) Uptake of pharmaceutical and personal care products by soybean plants from soils applied with biosolids and irrigated with contaminated water. Environ. Sci. Technol. 44, 6157-61

55 Prosser, R.S. et al. (2014) Modeling uptake of selected pharmaceuticals and personal care products into food crops from biosolids-amended soils. Environ. Sci. Technol. 48, $11397-11404$

56 Richter, E. et al. (2013) Ecotoxicity of climbazole, a fungicide contained in antidandruff shampoo. Environ. Toxicol. Chem. 32, 2816-2825

57 Wilson, B.A. et al. (2003) Effects of three pharmaceutical and personal care products on natural freshwater algal assemblages. Environ. Sci. Technol. 37, 1713-1719 
Table 1. Examples of pharmaceuticals and personal-care products (PPCPs) in the influent and effluent of plants for treating wastewater

Family of contaminant of emergent concern

Analgesics and anti-inflammatory

Anti-diabetics

Anti-epileptics

Anti-estrogenics

Anti-histaminics

Anti-protozoals

Antiseptics

Lipid regulators

Diuretics

Medication used to treat erectile dysfunction and pulmonary arterial hypertension

Psychiatric drugs and antidepressants

Psycho-stimulants

Veterinary and human antibiotics

\section{$\beta$-blockers}

$\mathrm{X}$-ray and contrast media

Cosmetics and personal-care products

Surfactants

Phytosanitary products

\section{Examples}

Codein, diclofenac, fenoprofen, ibuprofen, indomethacine, ketoprofen, ketorolac, paracetamol, phenylbutazone, naproxen, clofibric acid

Metformin

Carbamazepine, 4-aminoantipyrine, antipyrin, codein, diclofenac

\section{Tamoxifen}

Dephenhyldramine

Quinacrine dihydrochloride

Triclosan, chlorophene

Acebutolol, atenolol, atorvastatin, bezafibrate, fenofibric acid, gemfibrozil

Furosemide, hydrochlorothiazide, amidotrizoic acid, diatrizoate, iotalamic acid

Sildenafil

Diazepan, fluoxetin

Caffeine, paraxanthin

Azithromycin, chlortetracycline, clarithromycin, ciprofloxacin, doxycyclin, enrofloxacin erythromycin, erythromycin- $\mathrm{H}_{2} \mathrm{O}$, levofloxacin, lincomycin, methronidazole, norfloxacin, ofloxacin, oxytetracycline roxithromycin, salinomycin, sulfamethazine, sulfamethoxazole, sulphadimethoxine, sulfapyridin, tetracyclin, trimethoprim, tylosin

Celiprolol, metoprolol, propanolol, sotalol, timolol

Iopromide, iopamidol, iohexol, diatrizoate

Benzophenone, galaxolide, N,N-diethyltoluamide, tonalide, triclosan, triclocarban

PFOA, tergitol

Clofibric acid 
Table 2. Minimum and maximum concentration of pharmaceuticals and personal-care products (PPCPs) in microalgae and crops from agricultural fields, and the subsequent phytoxicicity effect of each compound under realistic field conditions ${ }^{\mathrm{a}}$

\begin{tabular}{|c|c|c|c|c|c|c|c|c|}
\hline \multicolumn{2}{|c|}{ Compound } & \multicolumn{3}{|c|}{ Concentration } & \multicolumn{4}{|c|}{ Phytotoxicity } \\
\hline & & Plants & Min-max ${ }^{b}$ & Ref. & Plants and algae & Effect & Conc. ${ }^{\mathrm{c}}$ & Ref. \\
\hline \multirow[t]{2}{*}{$\begin{array}{l}\text { Analgesics } \\
\text { and anti- } \\
\text { inflammatory }\end{array}$} & Diclofenac & $\begin{array}{l}\text { Lettuce (Lactuca sativa), } \\
\text { carrot (Daucus carota) }\end{array}$ & $\begin{array}{l}\text { nd-19 } \mu \mathrm{g} \\
\mathrm{kg}^{-1} \text { dry } \\
\text { weight }\end{array}$ & {$[20]$} & $\begin{array}{l}\text { Microalga } \\
\text { (Pseudokirchneriell } \\
\text { a subcapitata) }\end{array}$ & Growth reduction & $10 \mathrm{mg} \mathrm{L}^{-1}$ & {$[44]$} \\
\hline & Ibuprofen & $\begin{array}{l}\text { Lettuce (Lactuca sativa), } \\
\text { carrot (Daucus carota) }\end{array}$ & $\begin{array}{l}\text { nd-30 } \mu \mathrm{g} \\
\mathrm{kg}^{-1} \text { dry } \\
\text { weight }\end{array}$ & {$[20]$} & $\begin{array}{l}\text { Great millet } \\
\text { (Sorghum bicolor) }\end{array}$ & $\begin{array}{l}\text { Decreased quantum } \\
\text { efficiency of } \\
\text { photosystem II \& } \\
\text { photochemical } \\
\text { quenching coefficient }\end{array}$ & $\begin{array}{l}83 \mathrm{mg} \mathrm{kg}^{-1} \\
\text { dry weight, } \\
\text { spiked soil }\end{array}$ & [45] \\
\hline $\begin{array}{l}\text { Anti- } \\
\text { diabetics }\end{array}$ & Metformin & $\begin{array}{l}\text { Barley sedes (Hordeum } \\
\text { vulgare) }\end{array}$ & $\begin{array}{l}\text { nd- } 440 \mu \mathrm{g} \\
\mathrm{kg}^{-1} \text { dry } \\
\text { weight }\end{array}$ & {$[46]$} & $\begin{array}{l}\text { Carrot (Dacus } \\
\text { carota) }\end{array}$ & $\begin{array}{l}\text { Growth and } \\
\text { development reduction }\end{array}$ & $\begin{array}{l}10 \mathrm{mg} \mathrm{kg}^{-1} \\
\text { dry weight, } \\
\text { spiked soil }\end{array}$ & [46] \\
\hline \multirow[t]{5}{*}{$\begin{array}{l}\text { Veterinary } \\
\text { and human } \\
\text { antibiotics }\end{array}$} & Amoxicillin & $\begin{array}{l}\text { Chinese white cabbage } \\
\text { (Brassica rapa), water } \\
\text { spinach (Ipomoea aquatica), } \\
\text { rice (Oryza sativa), Chinese } \\
\text { radish (Raphanus sativus), } \\
\text { corn (Zea mays) }\end{array}$ & $\begin{array}{l}2.6-22.4 \\
\mu \mathrm{g} \mathrm{kg}^{-1} \\
\text { dry weight }\end{array}$ & {$[47]$} & $\begin{array}{l}\text { Alfalfa (Medicago } \\
\text { sativa), Carrot } \\
\text { (Dacus carota), } \\
\text { Lettuce (Lactuca } \\
\text { sativa) }\end{array}$ & $\begin{array}{l}\text { Growth and } \\
\text { germination reduction }\end{array}$ & $\begin{array}{l}0.001-10 \\
\mathrm{mg} \mathrm{L}^{-1}\end{array}$ & {$[48]$} \\
\hline & $\begin{array}{l}\text { Chlortetracyc } \\
\text { line }\end{array}$ & $\begin{array}{l}\text { Corn (Zea mays), green } \\
\text { onion (Allium cepa), and } \\
\text { cabbage (Brassica oleracea) }\end{array}$ & $\begin{array}{l}2-17 \mu \mathrm{g} \\
\mathrm{kg}^{-1} \text { fresh } \\
\text { weight }\end{array}$ & {$[49]$} & $\begin{array}{l}\text { Alfalfa (Medicago } \\
\text { sativa), Carrot } \\
(\text { Dacus } \\
\text { carota),Lettuce } \\
\text { (Lactuca sativa) }\end{array}$ & $\begin{array}{l}\text { Growth and } \\
\text { germination reduction }\end{array}$ & $\begin{array}{l}0.001-10 \\
\mathrm{mg} \mathrm{L}^{-1}\end{array}$ & [48] \\
\hline & Sulfadiazine & $\begin{array}{l}\text { Winter wheat (Triticum } \\
\text { aestivum) }\end{array}$ & $\begin{array}{l}\text { nd- } 487 \mu \mathrm{g} \\
\mathrm{kg}^{-1} \text { dry } \\
\text { weight }\end{array}$ & {$[50]$} & Maize (Zea mays) & Death & $\begin{array}{l}10 \text { and } 200 \\
\mathrm{mg} \mathrm{kg}^{-1} \text { dry } \\
\text { weight, } \\
\text { spiked soil }\end{array}$ & {$[51]$} \\
\hline & Tetracycline & $\begin{array}{l}\text { Chinese white cabbage } \\
\text { (Brassica rapa), water } \\
\text { spinach (Ipomoea aquatica), } \\
\text { rice (Oryza sativa), Chinese } \\
\text { radish (Raphanus sativus), } \\
\text { corn (Zea mays) }\end{array}$ & $\begin{array}{l}4.0-10.1 \\
\mu \mathrm{g} \mathrm{kg}^{-1} \\
\text { dry weight }\end{array}$ & {$[47]$} & $\begin{array}{l}\text { Alfalfa (Medicago } \\
\text { sativa), carrot } \\
\text { (Dacus carota), } \\
\text { Lettuce (Lactuca } \\
\text { sativa) }\end{array}$ & $\begin{array}{l}\text { Growth and } \\
\text { germination reduction }\end{array}$ & $\begin{array}{l}0.001-10 \\
\mathrm{mg} \mathrm{L}^{-1}\end{array}$ & {$[48]$} \\
\hline & Tetracycline & $\begin{array}{l}\text { Radish (Raphanus sativus), } \\
\text { rape (Brassica napus), } \\
\text { celery (Apium graveolens) } \\
\text { and coriander (Coriandrum } \\
\text { sativum) }\end{array}$ & $\begin{array}{l}\text { nd-330 } \mu \mathrm{g} \\
\mathrm{kg}^{-1} \text { dry } \\
\text { weight }\end{array}$ & {$[52]$} & $\begin{array}{l}\text { Cucumber (Cucumis } \\
\text { sativus), Rice } \\
\text { (Oryza sativa), } \\
\text { Sweet oat } \\
\text { (Cichaorium } \\
\text { endivia) }\end{array}$ & $\begin{array}{l}\text { Growth and } \\
\text { germination reduction }\end{array}$ & $\begin{array}{l}0-500 \mathrm{mg} \\
\mathrm{L}^{-1}\end{array}$ & {$[53]$} \\
\hline $\begin{array}{l}\text { Cosmetics } \\
\text { and personal- } \\
\text { care products }\end{array}$ & $\begin{array}{l}\text { Triclosan } \\
\text { (antimicrobia } \\
1 \text { in liqued } \\
\text { soaps, } \\
\text { underarm } \\
\text { deodorants, } \\
\text { and } \\
\text { toothpastes) }\end{array}$ & $\begin{array}{l}\text { Soybean (Glycine max), } \\
\text { lettuce (Lactuca sativa), } \\
\text { carrot (Daucus carota), } \\
\text { radish (Raphanus sativus), } \\
\text { pepper (Capsicum), tomato } \\
\text { (Solanum lycopersicum), } \\
\text { lettuce (Lactuca sativa), } \\
\text { cucumber (Cucumis sativus) }\end{array}$ & $\begin{array}{l}24.2-80.1 \\
\mu \mathrm{g} \mathrm{kg}^{-1} \\
\text { dry weight }\end{array}$ & $\begin{array}{l}{[20,5} \\
4- \\
56]\end{array}$ & Freshwater alga & $\begin{array}{l}\text { Lower algal richness } \\
\text { and biomass }\end{array}$ & $\begin{array}{l}0.012-1.2 \\
\mu \mathrm{g} \mathrm{L} \mathrm{L}^{-1}\end{array}$ & [57] \\
\hline $\begin{array}{l}\text { Phytosanitary } \\
\text { products }\end{array}$ & Clofibric acid & $\begin{array}{l}\text { Lettuce (Lactuca sativa), } \\
\text { carrot (Daucus carota) }\end{array}$ & $\begin{array}{l}\text { nd-18 } \mu \mathrm{g} \\
\mathrm{kg}^{-1} \text { dry } \\
\text { weight }\end{array}$ & {$[20]$} & $\begin{array}{l}\text { Microalga } \\
\text { (Pseudokirchneriell } \\
\text { a subcapitata) }\end{array}$ & Growth reduction & $75 \mathrm{mg} \mathrm{L}^{-1}$ & [44] \\
\hline
\end{tabular}

Abbreviations: Conc, concentration; max, maximum; min, minimum; nd, not detected

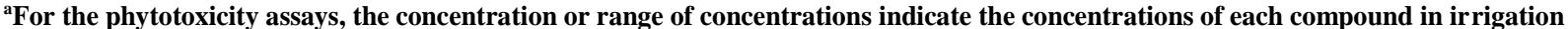
water applied to each soil (or directly the concentrations in soil) under which the plant showed a toxicological effect. Soils can achieve those PPCPs concentrations through the application of irrigation water, biosolids and animal manure to agricultural fields, or through experimental spikes of particular concentrations of PPCPs (spiked soil). Only compounds with available information on environmental and plant concentrations and phytotoxicities are presented.

${ }^{b}$ Min-max concentration in plants.

${ }^{\text {c}}$ Concentration studied in irrigation water $\left(\mathrm{mg} \mathrm{L}^{-1}\right)$ or in soil $\left(\mathrm{mg} \mathrm{kg}^{-1}\right)$ 


\section{Figure captions}

372 Figure 1. Main sources and fates of pharmaceuticals and personal-care products in plants

373 and the environment. Human activities are the main source of PPCPs in the environment,

374 which are concentrated in municipal, agricultural and industrial plants for treating wastewater.

375 PPCPs in reused irrigation water, biosolids and manure are applied to soils where they can

376 affect soil microbiota and can be taken up, accumulated and metabolized by plants. Aerial

377 uptake of PPCPs can also occur via deposition from volatilized compounds and aerosols and by

378 direct contact with irrigation water or amendment materials. PPCPs affect plants, their

379 microbiota and the subsequent food-web organisms feeding on them, including humans.

380 Abbreviations: PPCPs, pharmaceuticals and personal-care products.

382 Figure 2. Principal pathways of PPCP uptake in vegetation. The main parameters affecting

383 each pathway are annotated: $\mathrm{f}$ (function of), $\mathrm{K}_{\mathrm{OA}}$ (coefficient of octanol-air partition), V/P

384 (vapor-particle partitioning), SA (plant surface area), lipid (plant lipid concentration), Kow

385 (coefficient of octanol-water partition), solw $_{w}$ (water solubility) and $\operatorname{Org}_{\mathrm{s}}$ (organic content of the soil). Abbreviations: PPCP, pharmaceuticals and personal-care product. 